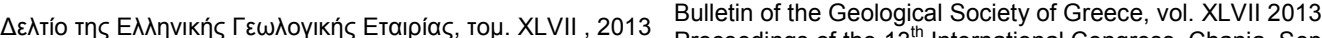
Xroceedings of the $13^{\text {th }}$ International Congress, Chania, Sept.

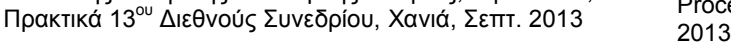

\title{
AGGREGATE PRODUCTION ON THE ISLAND OF CRETE, GREECE: CURRENT PRODUCTION CONDITIONS AND FUTURE PERSPECTIVE
}

\author{
Galetakis M. ${ }^{1}$, Zourbakis V. ${ }^{2}$, Koinakis I. ${ }^{2}$, Leventakis K. ${ }^{1}$ and Alevizos G. ${ }^{1}$ \\ ${ }^{I}$ Technical University of Crete, Department of Mineral Resources Engineering, Chania, Greece \\ ${ }^{2}$ NCSD/IGME Department of Crete
}

\begin{abstract}
Aggregate production is proven crucial for any infrastructure development, including construction work, for the island of Crete (Southern Greece), due to its individual geographical characteristics. Furthermore, since construction has traditionally been a dynamic sector of national economy, aggregate production is playing a major role in the economy of the island.

The aim of this study is to evaluate the current state of aggregate production in the island of Crete based on past and present production data and predict future demand under current state legal framework. Aggregate production and quality data, proven reserves within the state-defined "quarrying zones", as well as their spatial distribution are analyzed for every prefecture of the island. Prediction scenarios of future aggregate demand within the next 20 years are conducted, assuming different economic development rates. In each scenario the annual aggregate production as well as the remaining reserves per prefecture was predicted.
\end{abstract}

Key words: Aggregate, production, demand, quality characteristics, forecast, Crete.

\section{Пєрí $\eta \psi \eta$}

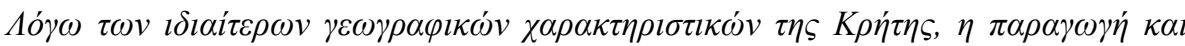

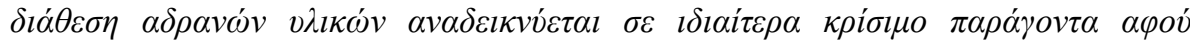

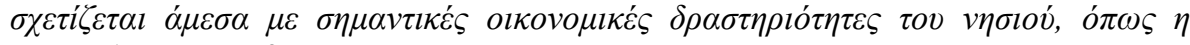

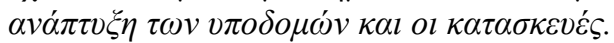

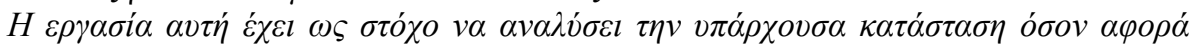

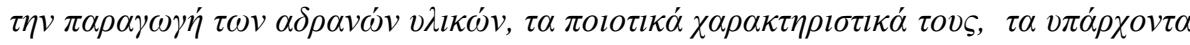

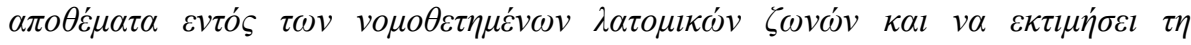

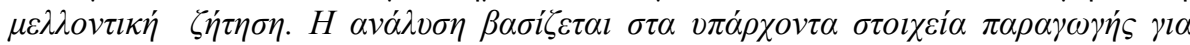

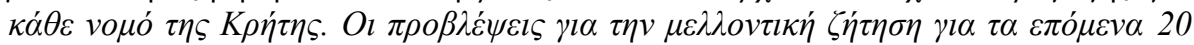

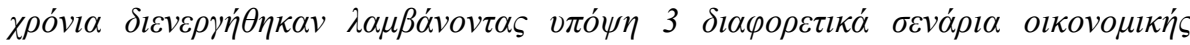

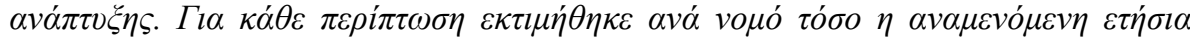
$\pi \alpha \rho \alpha \gamma \omega \gamma \eta \dot{~ o ́ \sigma o ~ \kappa \alpha l ~ \eta ~ \varepsilon \pi \alpha ́ \rho \kappa \varepsilon l \alpha ~ \tau \omega v ~ \alpha \pi о \theta \varepsilon \mu \alpha ́ \tau \tau \omega v ~ \varepsilon v \tau o ́ s ~ \tau \omega v ~ v \varphi l \sigma \tau \alpha \mu \varepsilon ́ v \omega v ~ \lambda \alpha \tau о \mu l \kappa \omega ́ v ~}$ $\zeta \omega v \omega ́ v$.

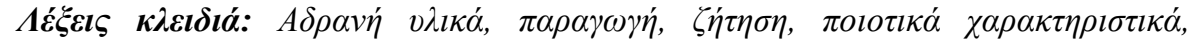

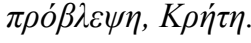

$\underline{\text { XLVII, No } 3 \text { - } 2030}$ 


\section{Introduction}

Aggregate materials are extensively used for all kinds of construction applications and infrastructure development and are essential for every modern economy. The most common natural aggregates of mineral origin are sand, gravel and crushed rock. Their main uses are: readymixed and precast concrete production, road paving, asphalt production, railroad ballast, mortar production, harbour construction and maintenance, cement and lime production.

The European aggregates production is about 3 billion tons/year, representing an annual turnover of approximately $€ 20$ billion. The production of aggregates is the largest extractive activity in Europe (excluding the mineral fuels sector) while demand is around to 5.5 tonnes per capita per year. The aggregates industry comprises some 14,000 companies (mostly SMEs), producing at approximately 24,000 sites with 250,000 people employed (including contractors) Within the European Union (EU-27), total aggregate production for 2010 was 2.78 billion tons according to 2011-2012 annual review of the European Aggregates Association (UEPG) (abbreviation UEPG stands for "Union Européenne des Producteurs de Granulats").

In certain countries of the European Community, natural sand and gravel, extracted from river beds or conglomerate formations, are dominating the market of aggregate material. These are mainly countries, whose geological conditions and/or terrain morphology make the production of crushed aggregates unprofitable or even illegal. On the other hand, in countries like Greece and Spain, among others, abundance and variety of easily extracted suitable rock formations, makes the choice of crushed aggregates far more advantageous for local construction works. Furthermore, in countries of Northern Europe, recycled aggregates originated mainly from construction and demolition wastes and in minor quantities from other industrial processes, have gradually risen to notable percentages, during the last decades. The origin (main sources) of the produced aggregate in Europe is shown in Figure 1 (UEPG, 2012).

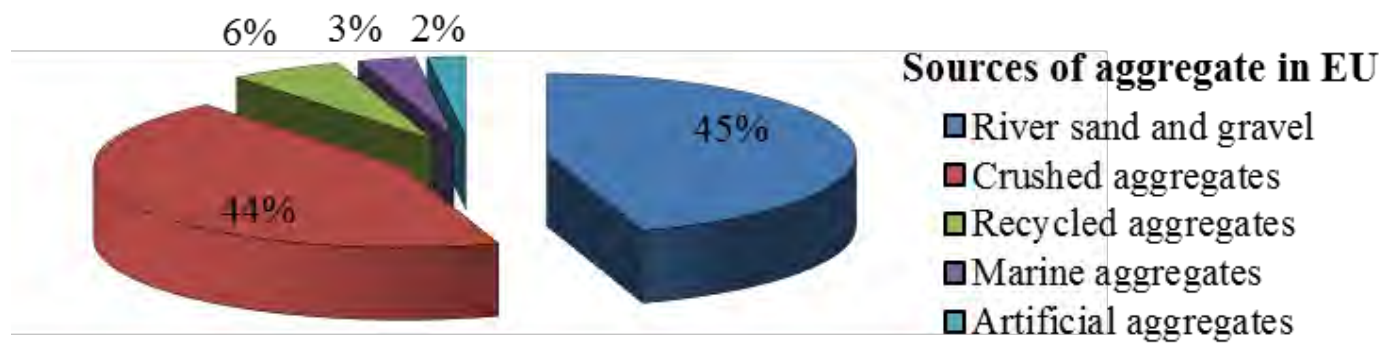

Figure 1 - Contribution of the different sources in total aggregate production in the European Union during 2005 (Source: www.uepg.eu).

In Greece approximately $90 \%$ of the produced aggregates are extracted via quarrying operations from calciferous rock formations (limestone), which are abundant and widespread all over the country. Quarrying is allowed within certain areas defined as quarrying zones. The percentage of each region's production (in comparison to the total production) for 2006 is shown in Table 1, while the percentage of produced aggregates size fractions is shown in Figure 2 (IGME, 2009).

Since concrete production and road paving are by far the most aggregate consuming construction activities in Greece, the common measured quality characteristics, related to such uses, are: Los Angeles value, sand equivalent value, water absorption, fines percentage and compressive strength of the source rock.

The basic statistical parameters of the aforementioned quality characteristics estimated by a large number of laboratory tests conducted according to European and ASTM standards (Los Angeles test: EN 1097-2:1998, sand equivalent test: EN 933-8, water absorption test: EN 1097-6, fines

XLVII. No 3-2031 
percentage: EN 933-1, compressive strength: ASTM C109) are shown in Table 2 (IGME, 2009). As can be seen from Table 2, as well as from frequency histograms depicted in Figure 3, water absorption and fines percentage indicates considerably higher variability, compared to the rest quality characteristics.

Table 1 - Regional distribution of quarry production for 2006 (IGME, 2009).

\begin{tabular}{|c|c|}
\hline Region & \% of total production \\
\hline Attica (prefecture hosting the capital) & 19 \\
\hline Sterea Ellada & 7 \\
\hline Thessaly & 12 \\
\hline Central Macedonia & 13 \\
\hline East Macedonia and Thrace & 5 \\
\hline West Macedonia & 4 \\
\hline West Greece & 5 \\
\hline Epirus & 5 \\
\hline Peloponnese & 11 \\
\hline Crete & 11 \\
\hline South Aegean Sea & 4 \\
\hline Ionian Islands & 2 \\
\hline North Aegean Sea & 2 \\
\hline Total & $\mathbf{1 0 0}$ \\
\hline
\end{tabular}

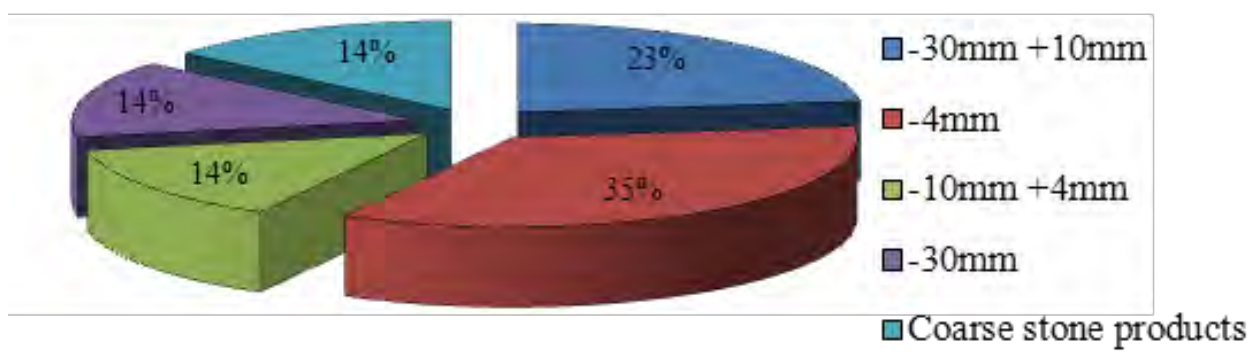

Figure 2 - Percentages of crushed aggregates sizes produced in Greece in 2006 (IGME, 2009).

Table 2 - Statistical data of quality characteristics of aggregates produced in Greece (IGME, 2009).

\begin{tabular}{|l|c|c|c|c|c|}
\hline & $\begin{array}{c}\text { Los } \\
\text { Angeles } \\
\text { value } \\
\%\end{array}$ & $\begin{array}{c}\text { Sand } \\
\text { equivalent } \\
\%\end{array}$ & $\begin{array}{c}\text { Water } \\
\text { absorption } \\
\%\end{array}$ & $\begin{array}{c}\text { Fines } \\
\text { percentage } \\
\%\end{array}$ & $\begin{array}{c}\text { Compressive } \\
\text { strength } \\
\mathrm{MPa}\end{array}$ \\
\hline Number of samples & 113 & 71 & 67 & 45 & 110 \\
\hline Average (m) & 26.4 & 71.1 & 0.5 & 13.5 & 71.1 \\
\hline Standard deviation & 4.3 & 5.6 & 0.3 & 7.0 & 5.6 \\
\hline Coefficient of variation \% & 16.4 & 7.9 & 55.0 & 51.7 & 7.9 \\
\hline
\end{tabular}

XLVII, No $3-2032$ 


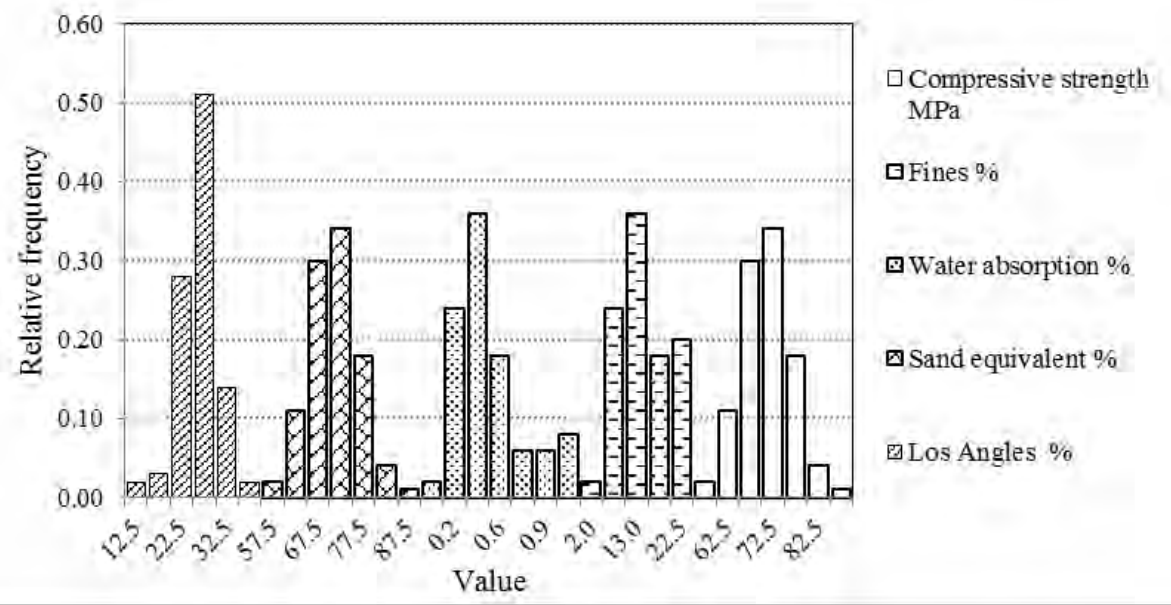

Figure 3 - Histograms of main aggregate quality parameters (Data source: IGME, 2009).

As far as state regulatory authority quarrying permits are concerned, definition of the zones of legitimate quarrying operation is a process that usually has to overcome numerous obstacles. Environmental and other restrictions set by state laws, in combination with local communities' reactions, are the main obstacles in defining new quarrying zones. Despite the aforementioned drawbacks, aggregate demand is met by production for almost all aggregate products, throughout the country, whilst shortages are restricted in the vicinity of the larger cities. The spatial distribution of aggregate quarries throughout Greece is quite uniform as can be seen in Figure 4.

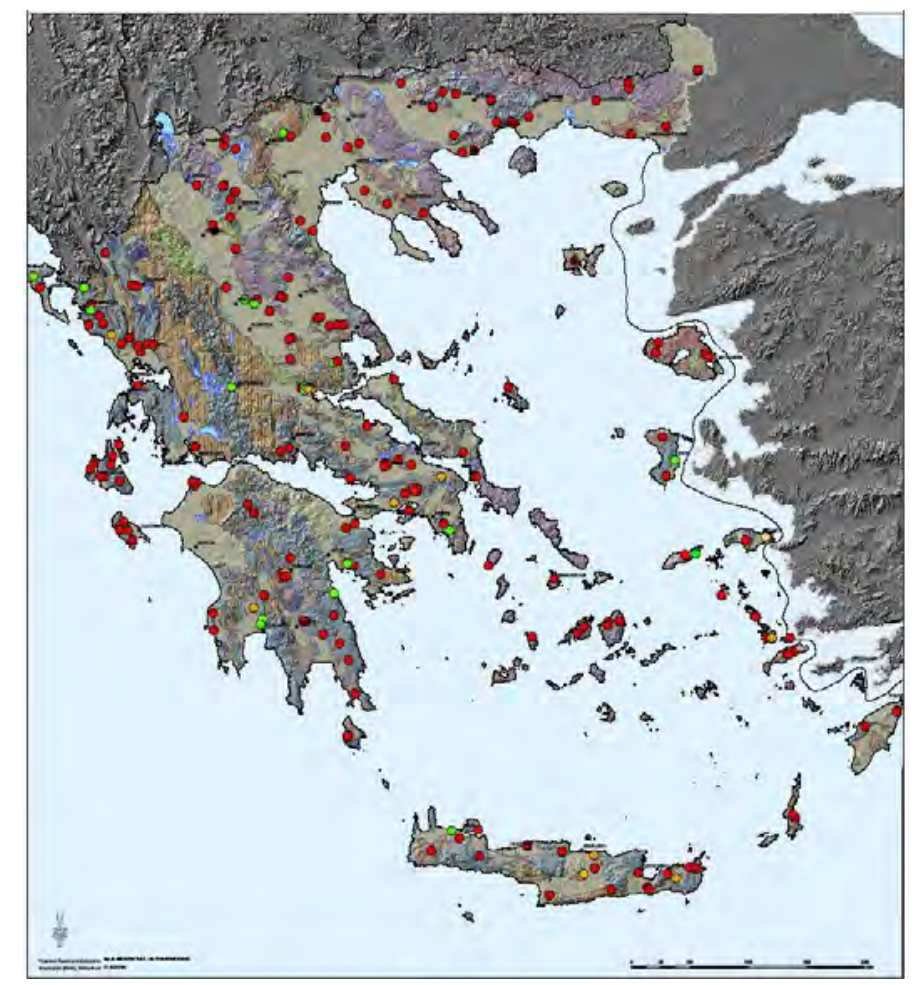

Figure 4 - Quarry distribution throughout Greece and operational status in 2011 (red dot: operating quarry, yellow dot: quarry under environmental reclamation (expended), green dot: currently non-operating quarry (Mines \& Quarries Inspectorate of Greece, 2013). 
In the following sections of this study the current state of aggregate production on the island of Crete, their quality characteristics and spatial distribution of production sites (quarries) are presented. Prediction scenarios of future market demand regarding the forthcoming two decades are examined and the geological availability, in terms of remaining reserves, is investigated.

\section{Quarry Production on the Island of Crete}

\subsection{Spatial Distribution of Quarries in Crete}

On the island of Crete, much like the rest of the country, a lot of diverse obstacles are met when quarry zones are to be defined. Hence, sites chosen for quarry zone delineation by the state bureau in charge (South Greece Mines \& Quarries Inspectorate), often meet strong opposition from local communities.

Quarrying sites, as shown in Figure 5, are evenly spread throughout the island. Their locations are mainly controlled by their distances to prefectures' capital cities (Chania, Rethymnon, Heraklion, Agios Nikolaos), which are the main marketplaces. They are operated mostly by small-size enterprises, with the exception of few medium-size, usually well organised and modernised companies. The number and the operational status of the quarries in the island of Crete are depicted in Table 3.

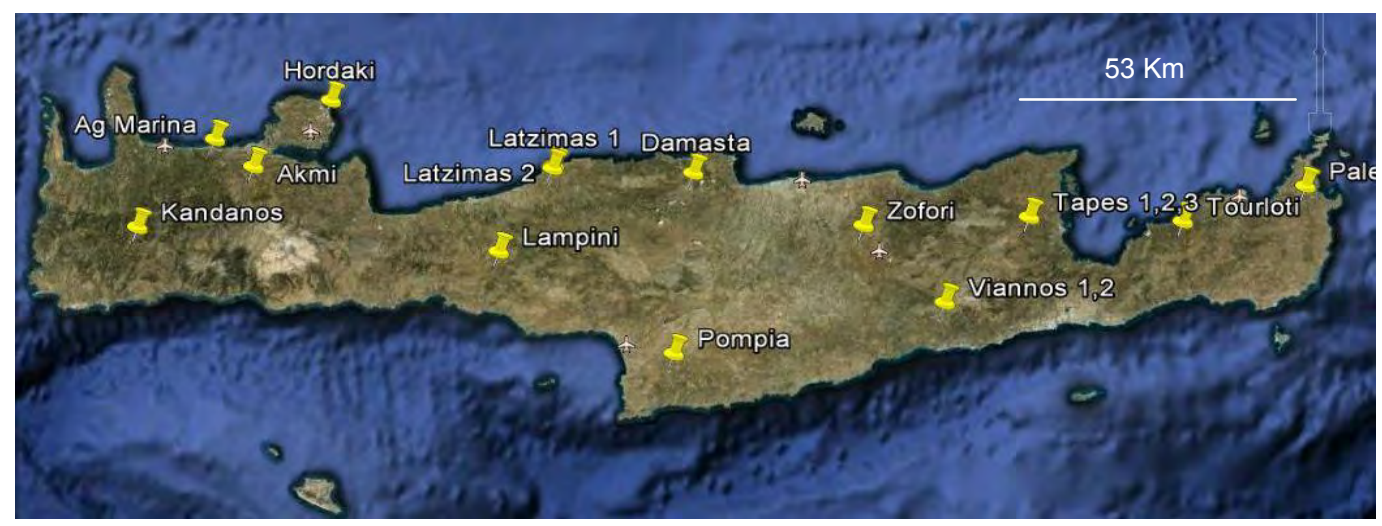

Figure 5 - Locations of quarrying zones on the island of Crete.

Table 3 - Operational status of quarries in Crete.

\begin{tabular}{|c|c|c|c|c|}
\hline $\begin{array}{c}\text { Operational } \\
\text { status }\end{array}$ & Operational & $\begin{array}{c}\text { Currently non- } \\
\text { operational }\end{array}$ & $\begin{array}{c}\text { In the process of } \\
\text { proper permit } \\
\text { obtainment }\end{array}$ & Special use \\
\hline Number & 7 & 4 & 1 & 4 \\
\hline $\begin{array}{c}\text { Operational } \\
\text { status }\end{array}$ & $\begin{array}{c}\text { Currently operating } \\
\text { outside the quarry } \\
\text { zones }\end{array}$ & $\begin{array}{c}\text { Depleted, under } \\
\text { environmental } \\
\text { reclamation }\end{array}$ & Depleted/Closed & \\
\hline Number & 1 & 4 & 6 & \\
\hline \multicolumn{5}{|c|}{ Total number of quarries =27 } \\
\hline
\end{tabular}




\subsection{Production Data of Aggregate Quarries in Crete}

The island of Crete is geographically and administratively divided in four prefectures, named from west to east: Chania, Rethymnon, Heraklion and Lasithi. The four major cities of the island are the capitals of each prefecture. Annual aggregate demand and production during 2000-2012 is divided among the four prefectures as shown in Figure 6. During 2000-2008 the total annual production level was relatively constant at $\sim 6.5 \mathrm{Mt}$. From 2009 to 2012 a significant decrease is observed, as a result of the economic recession (particularly in the construction sector). This decrease is higher for the prefecture of Heraklion, while the overall average decrease for the four prefectures, from 2008 to 2012 , was $\sim 70 \%$.

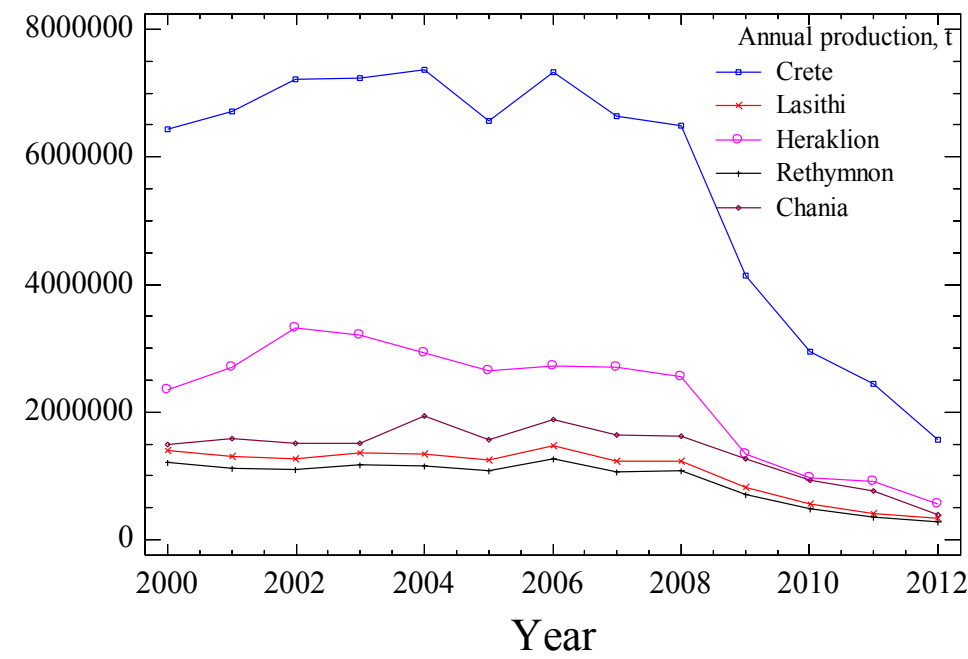

Figure 6 - Annual production of aggregates during 2000-2012 in Crete.

\subsection{Quality Characteristics of Aggregates Produced in Crete}

The basic parameters of aggregates quality data (Los Angeles, water absorption and compressive strength of the source rock) are given in Table 4. As far as compressive strength is concerned, measured values indicated that all operational quarries meet quality standard requirements for construction uses (EN 12620). Similarly Los Angeles and water absorption values satisfy quality requirements of construction works. In certain quarries (e.g. Viannos, Damasta) the source rock exhibits exceptional strength (over 100MPa). Aggregates extracted from such rocks, when also exhibiting low Los Angeles value, could be used in certain demanding applications.

\section{Estimation of Future Demand}

This section evaluates aggregate supply and demand scenarios within the island of Crete. It is assumed that equilibrium exists between supply and demand, while inventory levels are not considered significant therefore producers adjust to market needs.

The examined scenarios take into account the latest construction forecasts of the European Aggregates Association (UEPG). UEPG estimates that due to the European sovereign debt crisis there will be no overall growth in aggregates' production until 2014. Furthermore, based on the annual European average construction output increase (1.5\%) during 1992-2007, UEPG suggests that activity will not return to 2008's level until around 2023 (UEPG, 2012).

The model used for the estimation of aggregate demand is based on forecasts of construction activity, as well as, on forecasts of other economic factors, such as the Gross Domestic Product (GDP) (Poulin and Bilodeau, 1993). A multiple linear regression model, based on previous years'

$\underline{\text { XLVII, No } 3-2035}$ 
data, was developed. Initially the overall demand for the island of Crete is predicted by using the GDP and construction indices. The values of indices were taken from the Hellenic Statistical Authority's (ELSTAT) records and cover a period of 13 years, from 2000 to 2012.

Table 4 - Quality characteristics of aggregates produced in Crete

\begin{tabular}{|c|c|c|c|c|c|c|c|c|}
\hline Quarrying & \multirow{2}{*}{$\begin{array}{l}\text { Source } \\
\text { zone } \\
\text { description }\end{array}$} & $\begin{array}{l}\text { Number } \\
\text { of } \\
\text { samples }\end{array}$ & \multicolumn{2}{|l|}{ Los Angeles \% } & \multicolumn{2}{|l|}{$\begin{array}{l}\text { Water } \\
\text { absorption \% }\end{array}$} & \multicolumn{2}{|c|}{$\begin{array}{l}\text { Compressive } \\
\text { strength MPa }\end{array}$} \\
\cline { 4 - 9 } & & Mean & $\begin{array}{c}\text { St. } \\
\text { dev. }\end{array}$ & Mean & St. dev. & Mean & St. dev. \\
\hline Hordaki & $\begin{array}{c}\text { Tripolis } \\
\text { limestone }\end{array}$ & 3 & 32.6 & 0.9 & 0.8 & 0.1 & 74.7 & 7.5 \\
\hline Kandanos & $\begin{array}{c}\text { Ionian } \\
\text { limestone }\end{array}$ & 3 & 34.5 & 1.8 & 1.0 & 0.1 & 59.7 & 5.5 \\
\hline Akmi & $\begin{array}{c}\text { Tripolis } \\
\text { limestone }\end{array}$ & 3 & 28.5 & 1.9 & 1.1 & 0.1 & 64.0 & 7.9 \\
\hline Latsimas & $\begin{array}{c}\text { Tripolis } \\
\text { limestone }\end{array}$ & 6 & 28.2 & 2.1 & 0.8 & 0.1 & 85.0 & 7.5 \\
\hline Lambini & $\begin{array}{c}\text { Tripolis } \\
\text { limestone }\end{array}$ & 3 & 26.2 & 0.8 & 0.9 & 0.1 & 97.0 & 2.6 \\
\hline Damasta & $\begin{array}{c}\text { Ionian } \\
\text { limestone }\end{array}$ & 3 & 28.7 & 3.1 & 1.0 & 0.1 & 101.3 & 10.5 \\
\hline Zofori & $\begin{array}{c}\text { Tripolis } \\
\text { limestone }\end{array}$ & 3 & 30.0 & 1.0 & 1.0 & 0.1 & 98.0 & 4.2 \\
\hline Pompia & $\begin{array}{c}\text { Pindos } \\
\text { limestone }\end{array}$ & 3 & 31.0 & 0.5 & 1.0 & 0.1 & 75.3 & 20.6 \\
\hline Viannos & $\begin{array}{l}\text { Pindos and } \\
\text { Tripolis } \\
\text { limestones }\end{array}$ & 6 & 26.0 & 1.2 & 0.8 & 0.1 & 116.7 & 11.7 \\
\hline Tapes & $\begin{array}{c}\text { Tripolis } \\
\text { limestone } \\
\text { Total }\end{array}$ & 3 & 28.5 & 2.9 & 0.9 & 0.1 & 78.3 & 8.1 \\
\hline
\end{tabular}

According to ELSTAT methodology, indices are calculated by using constant values with base year 2005. For 2005 the GDP of Greece was $193050 \mathrm{M} €$ (2005 GDP index=100), while the turnover from construction activities was $14018 \mathrm{M} €$ (2005 Construction index=100). The aggregates production data of Crete were collected from the statistical records of the Greek Mines $\&$ Quarries Inspectorate. The developed model for the prediction of aggregates demand in Crete is given in equation 1 .

demand $=16780 * G D P_{i}+33390 * C_{i} \quad(\mathrm{R}=0.96)$

Where demand is the overall aggregate consumption in tons in Crete, $G D P_{i}$ is the Gross Domestic Product index and $C_{i}$ is the Construction index. $G D P_{i}$ and $C_{i}$ for Crete were considered equal to relevant national indices. 
The examined scenarios, S1, S2 and S3, shown in Figure 7, represent different forecasts for the evolution of GDP and construction indices during 2013-2033. S1 is considered as the optimistic, $\mathrm{S} 2$ the most probable, while S3 is the conservative. All scenarios consider negative rates for GDP and construction indices for 2013, zero change for 2014 and positive rates from 2015 to 2033. The assumed higher increase rate of construction index, in comparison to the increase rate of GDP, can be justified by previous years' data. According to this data, construction index has always exhibited a steeper change than GDP.

In a first step the annual aggregates production in the island of Crete, during 2013-2033, according to scenarios S1, S2 and S3 was estimated by using equation 1. Results, shown in Figure 8, indicate that the mean annual production of the period 2000-2008 ( $\sim 6.5 \mathrm{Mt})$ could be achieved in 2028 according to S1 and in 2033 according to S2. In the case of S3 the mean annual production of 2000-2008 cannot be reached within the examined period.

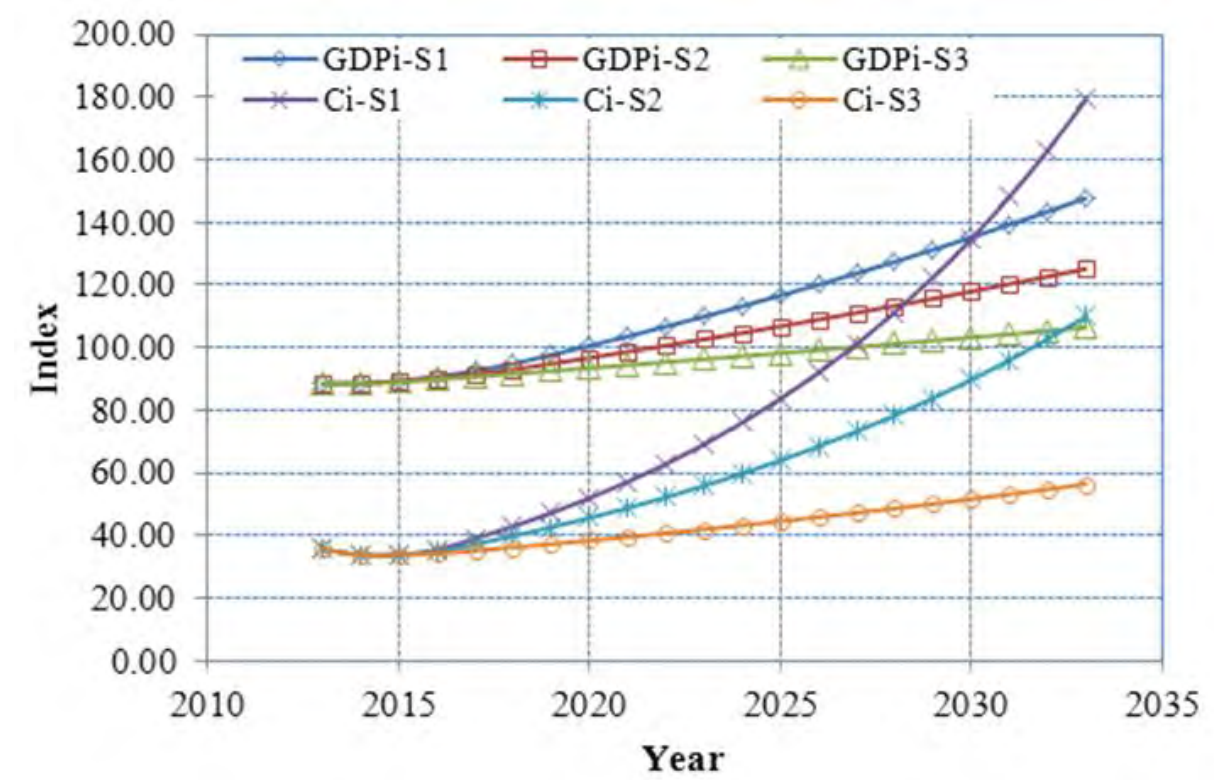

Figure 7 - Evolution of GDP and Construction indices for the examined scenarios (S1, S2 and S3) during 2013-2033 (GDPi-S1 denotes the evolution of GDP index according to scenario S1 and respectively for the other cases). 


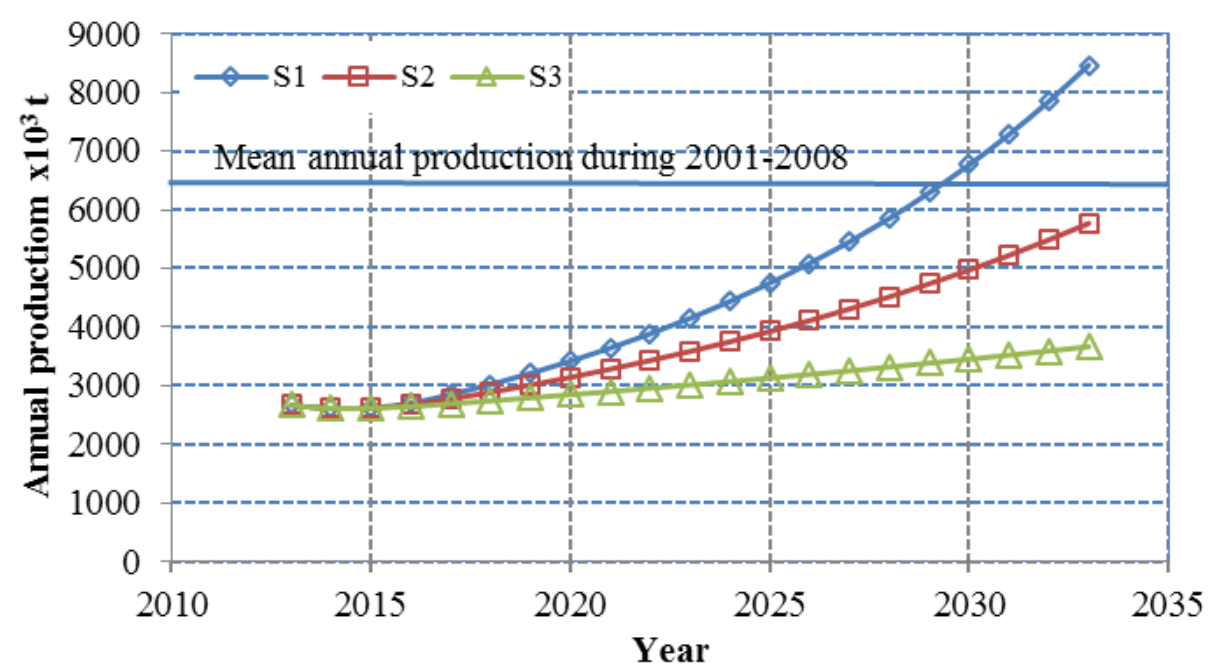

Figure 8 - Forecasts of annual aggregates production in the island of Crete, during 20132033, according to scenarios S1, S2 and S3.

In a second step the annual aggregates production for the prefecture of Crete was predicted. The percentage of each prefecture was estimated from its contribution to total aggregate production during 2000-2012. Furthermore the remaining exploitable reserves within the examined period were estimated (for the definition of a quarrying zone a feasibility study involving the estimation of the exploitable reserves is required). Initial reserves were considered the remaining exploitable reserves within the quarrying zones in 2012. These reserves were estimated as: 92Mt for Lasithi, 90Mt for Heraklion, 31Mt for Rethymnon and 28Mt for Chania.

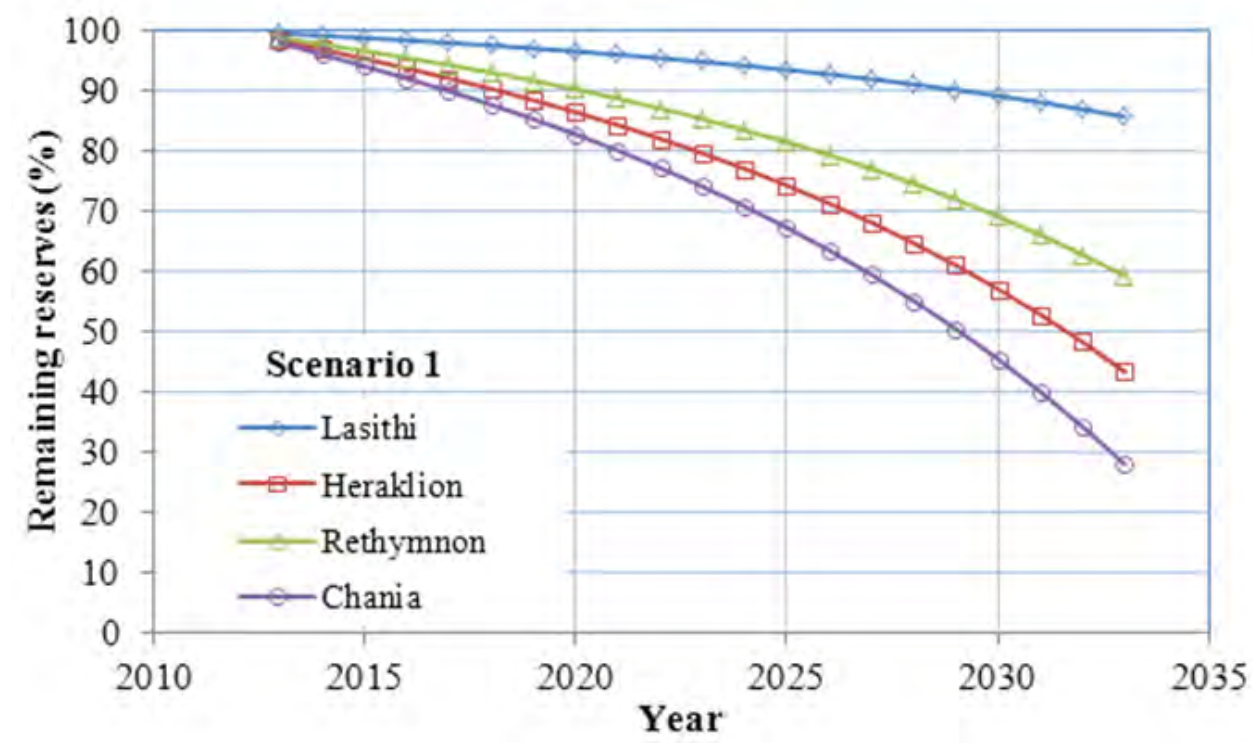

Figure 9 - Decrease of the remaining reserves (expressed as percentage of the initial reserves) in the municipalities of Crete according to the first scenario (S1).

The decrease of reserves for the first scenario S1 (represents the highest annual production) is shown in Figure 9. The largest remaining reserves (87\%) at the end of the examined period (2033) 
are those located in the prefecture of Lasithi, following by those of Rethymnon (59\%). In contrast the remaining reserves in Heraklion (43\%) and particularly in Chania (26\%) are low.

\section{Conclusions - Suggestions}

Aggregate production is an important economic activity for Crete as it is closely related to infrastructure development and to residential and other construction activities. However the annual production level has significantly decreased during the last four years as result of the economic recession and particularly in the construction sector. The laboratory tests indicated that the quality of produced aggregates meets the requirements for construction uses (EN 12620).

The existing resources within the quarrying zones in 2012 are considered sufficient. The examined aggregate supply and demand scenarios for the next twenty years (2013-2033) revealed that the remaining reserves for the prefectures of Lasithi and Rethymnon are still sufficient. For the prefecture of Heraklion and particularly for the prefecture of Chania, the remaining reserves will be insufficient by 2033, if the recovery in construction sector is as fast as considered in the optimistic scenario. For the remaining two, less optimistic scenarios, depletion will come after that date.

Since the present study does not consider constrains imposed by transportation cost, it is suggested to enhance current analysis by incorporating more complicated models for the prediction of aggregate production and demand. Such models should not only rely on the economic indices but also take into consideration the spatial distribution of quarries and market places.

\section{Acknowledgement}

Part of this study was carried out within the framework of DURECOBEL project. The authors affiliated with Technical University of Crete, would like to thank the General Secretary of Research and Technology of Greece for the financial support of the aforementioned project.

\section{References}

European Aggregates Association (UEPG). 2012. A Sustainable Industry for a Sustainable Europe, Annual Review 2011 - 2012. Available online at: www.uepg.eu.

Greek Mines \& Quarries Inspectorate 2013. Mining and Quarrying activities of Greece: Statistic Yearbook. Available online at: www.latomet.gr

Hellenic Statistical Authority (ELSTAT). Available online at: www.statistics.gr/portal/page/portal/ESYE/

IGME 2009. Atlas of crushed aggregates of Greece, Athens, p.118.

Poulin R. and Bilodeau M.L. 1993. A model of a mineral aggregate market, Resources Policy, June 1993, pp. 131-144. 